\title{
Early Slavophilism and European philosophy: the problem of correlation
}

\author{
Marina Shirokova ${ }^{1, *}$ \\ ${ }^{1}$ Altai State University, 656049, 61a Lenina ave., Barnaul, Russia.
}

\begin{abstract}
The article examines the question of the degree of influence the Western philosophy has on the philosophical concept of the founders of Slavophilism and the related question of the degree of independence of the philosophy of the Slavophils. The view is expressed that the problem of national identity, which became key to the Slavophile authors, was actively discussed at the beginning of the nineteenth century in the countries of Europe and from there penetrated into the Russian thought. It is said that the Slavophiles used the categorical apparatus and methodology of German classical philosophy, primarily the ideas of Hegel and Schelling. A comparison of the views of representatives of Slavophilism and Western European romanticism is conducted. The author concludes that the influence of Western philosophy on the concept of Slavophiles is undeniable, but the complex of Slavophilism ideas cannot be considered secondary to European ideas. The Slavophiles saw their task in creating an independent Russian philosophy, in which the synthesis of the cultures of Russia and the West on the basis of common moral values could be achieved.
\end{abstract}

\section{Introduction}

The question of the degree of influence of Western philosophy on the philosophy of the Slavophils and, accordingly, the degree of independence of the Slavophile concept, and together with it of all Russian philosophy, "due to the Slavophiles' efforts," is a question that presents not only simple cognitive interest. In the scientific community, there is a fairly widespread opinion that the Slavophil idea of national identity is an absolutely European problem that captured the minds of philosophers of all European countries at the beginning of the 19th century. And the fact is that this same problem soon began to be actively discussed in Russia once again reveals the belonging of the Slavophiles, as representatives of the educated class, to the European culture. True, in Europe the problem of national identity was key not for long and not for all directions of social and philosophical thought, it was a kind of alternative to the prevailing rationalist worldview, based on the idea of the universality of reason as the engine of progress. And the fact that in our Fatherland this problem has become the leitmotif of philosophy, often finding an explanation in the traumatic experience of the "catch-up modernization" that has formed in us a certain

\footnotetext{
* Corresponding author: mshirokova1@ rambler.ru
} 
complex of eternally lagging behind and the desire to prove that we are not lower or worse. Thus, according to the mentioned position, the Slavophiles created a speculative concept of what they called "nationality," which is the Russian version of the Western concept of "nationality," incorporating both the German ethnic content and the Anglo-French political one. It turns out that the content of the Slavophil philosophy is borrowed entirely, and the form is too. It is quite obvious that the discussion of the problem of the Russian nationality was carried out by the founders of Slavophilism with the help of the categorical apparatus and methodology of German philosophy.

\section{Slavophilism and European philosophy}

So, this opinion is quite widespread at the present time, but it goes back, in fact, to the 19th century. Already at that time, contemporaries drew attention to the Western ideological origins of the philosophical constructions of the Slavophiles. In 1856, I. V. Pavlov, a journalist close to the Slavophile circle and who was also in the house of the Aksakovs, wrote to his friend A. V. Malyshev, "Slavophiles are the blinded German children; but from the German scrofula has been laid their nose, they cannot smell the Russian people" [1]. A connoisseur and moderate critic of Slavophilism V. Chuiko was sure of the same, "There can be no doubt that Slavophilism ... is a product of the West. It was nourished by th eWestern civilization, strengthened by the study of the West and Western history, and justified as a scientific theory by the science of the West" [2]. In the works of A. N. Pypina, V. S. Solovyov, M. M. Kovalevsky, ans P.N. Milyukov is investigated the influence on the Slavophiles coming from the philosophy of Hegel and Schelling, the moods of European romanticism [3].

The study of European influences on Slavophilism was also carried out by the Western scholars of the 20th century. These authors just talked not only about the adoption of Slavophile thinkers' methods and techniques from the Western philosophic tradition, but also about borrowing the very problems being discussed. The American researcher P. Christoff, in particular, noted, "They (the Slavophiles - M. Sh.), paradoxicall turned to some of those problems that at this time were on the agenda rather in the West than in Russia" [4].

As we see, the idea of the non-Russian origin of Slavophilism continues to sound in the humanities and social sciences too aggressively, so as not listening to it. Some contemporary authors (for example, V. G. Grafsky) clarify that it should not be about the ordinary adaptation of Hegelianism, Schellingism, and Romanticism to Russia, but about their "Slavophile" adjustment [5]. However, this clarification does not abolish the basic proposition that Slavophilism as an integral system of views by its origin is almost entirely owed to the West.

The opposite opinion is expressed in the works of I. S. Aksakova, N. A. Berdyaeva, G. V. Florovsky, V. V. Zenkovsky, and M. N. Poltoratsky, who, while defending the idea of the original identity of Slavophilism, agured in favor of the Russian Orthodoxy being the origin of this ideology. Their judgments were based on the exaggeration of the other side of Slavophilism, namely its religious searches and appeals to Orthodox patristics [3].

The idea of the primordial identity of Slavophilism led researchers to the assertion that it had become a unique form of national consciousness. About this also wrote N. N. Strakhov, S. N. Trubetskoi, and, more recently, V. V. Kozhinov.

Without pretending to the fullness of the assessments, let us try to consider the degree of influence of Western philosophy on Slavophilism. First of all, let us dwell on the aspect of this influence, which is especially often mentioned in almost every article being published today. Almost every study devoted to Slavophiles uses the term of "conservative romanticism" or "romantic nationalism." These concepts, by the way, also have roots in the 
European research literature. They were used, in particular, by Edward S. Taden and Andrzej Walicki.

Indeed, the era of the late 18th century and about the first third of the 19th century is often called the era of Romanticism. Romanticism was a world phenomenon, reflected in all areas of culture of many countries. It was a kind of artistic and philosophical criticism of the contradictions of bourgeois civilization, all its inherent "vices," from rationalism and individualism to "industrialism." Western Europe, embraced by individualism, was conceived as a kind of Chaos: the world as being disjointed, fragmented, disunited, and lost its internal, "organic" connection. A special rejection was caused by the revolution, which appeared to be the product of this Chaos. Thus, the romantic outlook in the political sense had a conservative character, which, to a certain extent, was inherent in the teachings of the Slavophils.

Certainly, the comprehension of the pan-European romantic movement led the Russian educated society to a romantically interpreted idea of national identity, to the recognition of the uniqueness of its cultural and socio-political conditions. Russia, in this philosophical and artistic context, became the embodiment of the Cosmos, the "organic," the "one" world, which, according to the Slavophils, belonged to the future. The West, not without the direct influence of conservative German romantics A. Müller, F. Schlegel, and especially F. Baader, appeared to the Russian Slavophiles as a community of nations that had already passed the highest point of their development. Among the Romantics, especially Schelling, "organicism" was also adopted as the basic principle of social development. The organic category generally occupies an exceptional place in the theoretical constructions of Slavophilism [6]. But in comparison with the concepts of German Romantics among the Slavophiles, organicism acquired a much more pronounced anti-statist tinge.

It is impossible not to see other significant differences, sometimes making Slavophilism and European conservative romanticism opposite to each other. G. V. Plekhanov had the reason to assert that "the spiritual soil on which our Slavophilism grew was in many respects different from the one that gave rise to Western European romanticism" [7]. Russian sobornost, community, choral beginning, unity of love and freedom, which does not recognize any formal guarantees and any external authority, do not fit into a conservative value system. In addition, the Slavophile socio-political doctrine was hostile to aristocracy and elitarism, it, according to N. A. Berdyaev, was imbued with a kind of democracy.

The Slavophils opposed the inviolability of class division, were against noble privileges, strict hierarchy of society (on which, in the opinion of the conservatives, order is maintained). The Slavophile concept of personality is opposed to the Western romantic image of the "hero of history," "Übermensch". In the case of Western Romantics, the hero resists the crowd, the gray mass, seeking to either dominate it, or, if this is not possible, to turn away from it, becoming locked in itself. As I.V. Kireevsky states, he "takes comfort in thinking that ... it is useless to resist force and interfere in the affairs of the people who survived from the mind" [8]. Russian Romantics, however, proclaimed that man only finds himself in society, becomes a value, and the most important aspect of the meaning of a person's life is to benefit his people. This was said by the Lyubomudry, the predecessors of the Slavophils.

Another curious difference between the philosophy of the Slavophils and the conservative and romantic tradition is the boundless belief in the good nature of man, the complete absence of evil themes in Slavophile philosophy as such (except for certain publicist attacks by K. S. Aksakov, which did not receive any proper philosophical formulation). In general, the Slavophil world outlook does not allow any absolutely evil beginning, for which the Slavophiles were later criticized by some Orthodox philosophers, 
primarily K. N. Leontiev. V. V. Zenkovsky pointed to the "significant gap" in the anthropology of Khomyakov, "He does not have the doctrine that there is evil in man and from where it" [9]. And even N. A. Berdyaev reproached Khomyakov for not revealing, in particular, the satanic nature of the state, "... and it is unlikely that he could come to terms with the idea of eternal hell torment" [10]. That is, the Slavophils were so humane that, in his opinion, for all their religiousness, they hardly believed completely in hell and in the devil. Incidentally, the distinctive feature of the great Russian literature of the 19th century is the absence of unambiguously negative characters in it. There is a choice between good and evil, but there is no fatal evil.

Speaking about the influence of Western philosophy on the formation of Slavophilism, it is impossible not to mention Hegel. Hegelian dialectics, rethought in the Slavophile spirit, became one of the main components of the Slavophile methodology in their philosophical, political, historical, and even theological constructs. It is no accident that K. S. Aksakova and Yu. F. Samarin in his youth was called the "Orthodox Hegelians." A detailed examination of the influence of Hegel's philosophy on Slavophilism is a separate and large subject, because the influence is undeniable and very great, even more than the Slavophile ideologists themselves actually admit. But here we would like to point out one of the reasons, which is extremely important from the point of view of the topic under consideration and on which the philosophical system of the great German thinker evoked criticism from the Slavophiles. This is precisely the fundamental difference between the Slavophile (and later all Russian) philosophy from the West.

The fact is that the Slavophiles did not see a clearly expressed value orientation in Hegel's concept. And any philosophy, according to the Slavophiles, should have a double result or, more precisely, two sides of its "last result": one of them is the total final knowledge of the world and the laws of its development (that is, actually, science), and the other one is "the ruling requirement" arising from this knowledge. Comprehension of philosophy should orient people to certain goals and values, "which they will seek in science and in life." In other words, a person must understand why and for the sake of what he/she lives, including in the name of what it is necessary to know the world. In the Slavophile language, these values are most often denoted by the word "faith," which is objectively understood, based on the conditions of that time.

In 1856, in the last year of his life, Kireevsky formulated the Slavophile concept of the genesis of philosophy: philosophy emerges when "the two opposite ends of human thought" unite, the first of which is faith, and the second is the development of sciences and external education." Thus, the philosophy, by definition, given by Kireyevsky, "is nothing other than a transitional movement of the human mind from the domain of faith into the diverse application of everyday thought" [11]. As F. I. Girenok writes, "Religious philosophy, or religious thinking, was to preserve the feeling and thought in their unity. This was the intention of I. Kireevsky, who conceived the idea of creating an Orthodox philosophy. Philosophy is not a science. But this is not faith. This is an intermediary. A guide between science and faith. If you are out of science, then it will lead to faith. And vice versa. Philosophy itself is meaningless" [12], it becomes the destroyer of a sympathetic connection between people.

Therefore, Western philosophy evoked dissatisfaction among the Slavophils because of its claims to complete objectivity and universality, their desire for maximum freedom from moral, political, religious, and national predilections, revered in Europe for one of the main advantages of any scientific system. But the desire to get rid of a visible connection with any values, according to the Slavophils, not only does not enrich, but, on the contrary, impoverishes, emasculates any philosophical concept, which is an additional proof of the isolation of Western philosophy from life. Philosophy becomes an immoral, pure technology, part of an anthropogenic civilization that can ruin both culture and society 
itself. Rationalistic philosophy strives to be a pure form, being alienated from content, demonstrating, in the words of Kireevsky, "lack of character" of "external, logical, and technical education."

Most of all, the criticism of "spinelessness" of the Slavophils was addressed to Hegel's philosophy. They considered his philosophical system as being the highest point of development in Western education, followed by a complete disappointment in the possibilities of abstract reason. Kireevsky concludes that Hegel's philosophy does not require anything from man, does not lead anywhere. For by its nature it is "something between good and evil, between the power of exaltation and the power of distorting a person," it only "silently" transmits abstract knowledge, "which can be equally used for good and for harm, for serving truth or for reinforcement lies" [8]. The Slavophiles, however, set themselves the task of developing a moral philosophy that does not allow such contradictory interpretations.

\section{Conclusion}

So, the influence of the ideas of Hegel, Schelling, and German Romantics on Slavophilism is undeniable. However, as N. I. Tsimbayev states, it cannot be the basis for reducing Slavophilism to the interpretation of these ideas in Russia, and even more so for affirming the idea of the secondary character of Slavophilism in relation to German classical philosophy and romanticism [3]. A. S. Khomyakov considered European philosophy as a stage in the spiritual development of all mankind, in relation to which the philosophy of the Slavophils was to become a qualitatively new stage. "Only a clear knowledge of the former schools of philosophy gives the right to recognize their error and incompleteness and to try to create a new, fuller and more rigorous teaching" [13], wrote Khomyakov in 1837.

In turn, Kireevsky assertes, "I think that German philosophy... can serve as the most convenient stage of thinking for us from the borrowed systems to the lybomudriye conducted by ourselves" [8].

Thanks to the Slavophiles, as the contemporary author V. I. Kholodny writes, It was in [original Russian philosophy] (and only in it), in which the reflection of classical European philosophy was not only freed from alienated objectification, but also reunited with the traditional fullness of human existence still being preserved in Russia of that time" [14]. And he continues further, "The center of philosophical axiological creativity gradually began to move to Russia." Of course, the Slavophils created Russian philosophy as a religious one, and subsequently N. A. Berdyaev and V. V. Zenkovsky noted that all Russian philosophers, even materialists, had a religious mentality. But, indeed, it would be fairer to say more broadly: "All Russian thinkers are characterized by ... deep holistic axiology" [17], not so much the religious mentality but the value mentality, the appeal to the human in people, the desire not only to dispassionately comprehend the laws of the surrounding world and transform it with the help of science and technology, but to morally assess their actions. This is extremely important in the contemporary world.

\section{References}

1. A. I. Balandin, P. I. Yakushkin, From the history of Russian folklore (Nauka, Moscow, 1969)

2. V. V. Chuiko, Nabludatel, 3 (1890)

3. N. I. Tsimbayev, Socio-political views of the Slavophils (Moscow, 1986)

4. P. Christoff, An introduction to nineteenth-century Russian Slavophilism: a study of ideas (San-Francisco State College, Mouton, 1961) 
5. V. G. Grafsky. Political and legal views of the Russian narodniki (Nauka, Moscow, 1993)

6. E. G. Soloviev, Polis, 3 (1997)

7. G. V. Plekhanov, Works, Volume 23 (Partizdat, Moscow, 1926)

8. I. V. Kireevsky, Selected articles (Sovremennik, Mosow, 1984)

9. V. V. Zenkovsky, History of Russian philosophy (Ego, Leningrad, 1991)

10. N. A. Berdyaev, Alexei Stepanovich Khomyakov (Put, Moscow, 1912)

11. I. V. Kireevsky, Complete Works, Volume 2 (Put, Moscow, 1911)

12. F. I. Girenok, Pathology of the Russian mind: mapping of literalness (Agraph, Moscow, 1998)

13. A. S. Khomyakov, Philosophskiye Nauki, 11 (1991)

14. V. I. Kholodny, A. S. Khomyakov and modernity: the origin and perspective of the cathedral phenomenology (Akademicheskiy Prospekt, Moscow, 2004) 